\title{
Threatened fishes of the world: Acipenser schrenckii Brandt, 1869 (Acipenseridae)
}

\author{
Xuezhen Zhang $\cdot$ Dapeng Li
}

Received: 21 October 2008 / Accepted: 31 March 2009/Published online: 18 April 2009

(C) Springer Science + Business Media B.V. 2009

Common name: Amur sturgeon (English). Conservation status: Endangered-IUCN Red List, Classified under Appendix II of CITES, Endangered-China Species Red List. Identification: D 35-54, A 19-33, P 35, V 25. Five rows of scutes: D 11-19, L 30-47, V 4-11. Gill rakers: 31-48 (Zhang 1995). Triangular head, inferior and small mouth elongated and depressed snout, two pairs of barbels (Yue and Chen 1998). There are two distinct morphs of Amur sturgeon: brown and grey (Krykhtin and Svirskii 1997). Figure from Wei et al. (1997). Distribution: The species is distributed throughout the Amur River basin, as well as the Ussuri and Sungari (Songhuajiang) rivers, and also can be found in Japan due to the possibility of anadromous migration (Shmigirilov et al. 2007). Abundance: Declining dramatically from the 1930s, with natural stock unknown as yet. Habitat and ecology: A typical benthic feeder. Feeds on bottom invertebrates and mollusks, as well as small fishes (Shmigirilov et al. 2007). Dwells in the middle to lower layers of deep eddy currents. Reproduction: Late sexual maturity (7-24 years). Spawning period from late May to early July. Fecundity ranges from 114000 to 1292 000 with mean of 385000 (Zhang 1995). Threats: Stock has been destroyed by illegal poaching and overfishing (Yue and Chen 1998). Contamination of the Amur River and its tributaries is also a potential threat. Conservation action: Local regulations for the

X. Zhang $(\bowtie) \cdot$ D. Li

Fisheries College of Huazhong Agricultural University, Wuhan 430070, China

e-mail: xuezhen@mail.hzau.edu.cn

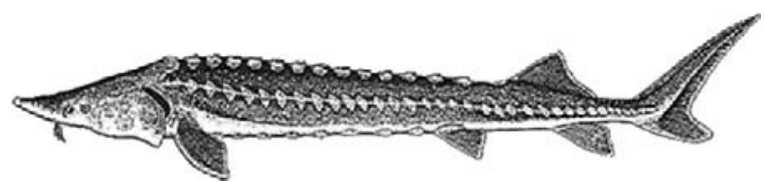

protection, enacted in the 1950s and renewed in 1982, and conservation efforts by China in 1998 were insufficient to prevent stock decline. Collaboration and cooperation between China and Russia play a crucial role in Amur sturgeon conservation. Conservation recommendations: Fishing regulations must be strictly implemented, with emphasis on fishing prohibition period and areas. Artificial hatching and releasing of raised young Amur sturgeons into rivers should be considered.

\section{References}

Krykhtin ML, Svirskii VG (1997) Endemic sturgeons of the Amur River: kaluga, Huso dauricus, and Amur sturgeon, Acipenser schrenckiii. Environ Biol Fish 48:231-239

Shmigirilov AP, Mednikova AA, Israel JA (2007) Comparison of biology of the Sakhalin sturgeon, Amur sturgeon, and kaluga from the Amur River, Sea of Okhotsk, and Sea of Japan biogeographic Province. Env Biol Fish 79:383-395

Wei QW, Ke F, Zhang JM, Zhuang P, Luo JD, Zhou RQ, Yang WH (1997) Biology, fisheries, and conservation of sturgeons and paddlefish in China. Env Biol Fish 48:241-255

Yue PQ, Chen YY (1998) China Red Data Book of endangered animals-Pisces. Science. Beijing, Hong Kong, New York, pp 6-8

Zhang JM (1995) Fishery resources of Heilongjiang Province. pp. 24-34. Scientific and Technical Publishing House of Heilongjiang (in Chinese) 